\title{
From Brownian motion to molecular simulations
}

\author{
Rovenchak A. ${ }^{1}$, Trokhymchuk A. ${ }^{2}$ \\ ${ }^{1}$ Department for Theoretical Physics, Ivan Franko National University of Lviv, \\ 12 Drahomanov Str., Lviv, 79005, Ukraine \\ ${ }^{2}$ Institute for Condensed Matter Physics \\ of the National Academy of Sciences of Ukraine, \\ 1 Svientsitskii Str., Lviv, 79011, Ukraine
}

(Received 21 December 2018)

\begin{abstract}
A brief historical overview towards the contribution of two famous Lviv scholars - Marian Smoluchowski and Stanisław Ulam - to the development of modern physical science fields such as molecular modeling and computer simulations is presented and discussed in connection with recent studies carried out in Lviv universities and research institutions.
\end{abstract}

Keywords: history of science, Monte Carlo simulations, molecular dynamics simulations, first principles ab initio simulations

2000 MSC: 01A60, 82-03, 82C40, 82D30, 60J65

UDC: $53(091), 501,533.723,544.77$

DOI: $10.23939 / \mathrm{mmc} 2018.02 .099$

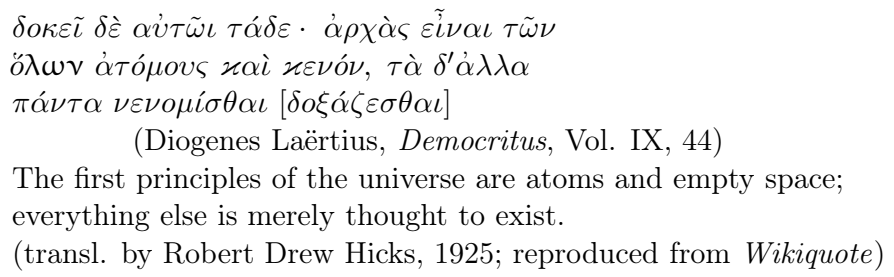

\section{Introduction}

Brownian motion was discovered, most probably, in the late 18th century by a Dutch scholar Jan Ingen-Housz (1730-1799) [1] and is known after the name of a Scottish botanist Robert Brown (17731858), who observed the chaotic motion of pollen grains in water [2]. For the detailed history of studies on the phenomenon of Brownian motion, one can refer to [3-5].

Discovery of Brownian motion was important for development of physics from various reasons. One of them was kinetic or molecular approach in the theory of gases and liquids. From this point of view the experimental observations of Jean Baptiste Perrin (1870-1942) in 1908 [6] were decisive in overall acceptance of the atomic-molecular structure of matter. This idea, being expressed yet in the 5th century BCE (see the epigraph), had been struggling for the minds of the researchers through the 19th century to finally won during the first decade of the 20th century only.

An important turning point in this direction were theoretical explanations of Brownian motion published in 1905 by Albert Einstein [7] and in 1906 by professor of University of Lviv Marian Smoluchowski [8] who elaborated the ideas of celebrated kinetic theory due to James Maxwell and Ludwig Boltzmann. Following Daniel Bernoulli who as early as in 1738 introduced the elastic hard-core molecules to understand the microscopic origin of the pressure of the gases, Boltzmann in the nineteenth century (throughout the period 1866-1871 [9]) constructed the original kinetic theory based on the hard-sphere model of rarefied gas.

The confirmation of the atomic-molecular structure of matter opened way to the development of statistical physics, where various approximate theories, such as the van der Waals theory, virial 
expansions, integral equations and perturbation theory approaches, etc. to understand the properties and solve problems of many-body systems have, been developed. Unfortunately, all these theoretical approaches have involved certain approximations and were not exact. Therefore, the results obtained could not provide definitive answer since it was not clear whether particular theoretical approach fails or used model, e.g., hard-sphere model, is not adequate.

The progress in statistical physics was accompanied by the development of computing machines. The middle of 20th century concerns with the revolutionary development of electric computers and computer simulation methods. In 1953, the pioneering computer simulations of two-dimensional hard sphere system by Monte Carlo method were reported by Metropolis et al. [10]. Although his name was not on the list of authors, but with this paper another Lviv scholar - Stanisław Ulam - now is entering the present story. On page 1088 of their paper [10] by introducing the Monte Carlo method to calculate "a several-hundreds dimensional integral" the authors made a note: "This method has been proposed independently by J. E. Mayer and by S. Ulam. Mayer suggested the method as a tool to deal with the problem of the liquid state, while Ulam proposed it as a procedure of general usefulness." Nowadays Monte Carlo method together with molecular dynamics (classical and ab initio) method are forming basis of the powerful research technology known as computer simulations or computer experiment to explore the physical and chemical properties of the condensed matter, both the soft and solid.

The described chain of events illustrates that Marian Smoluchowski (1872-1917) and Stanisław Ulam (1909-1984), who never met during their life although short period of time after Ulam birth in 1909 and before Smoluchowski departure in 1913 to Krakow were living in Austro-Hungarian Empire in the same city at that time called Lemberg (now City of Lviv in Ukraine), in reality are leading actors in a history of science story entitled "From Brownian motion to molecular simulations". In the following Sections 2 and 3, we give biographical sketch of Marian Smoluchowski and Stanisław Ulam and briefly analyze their contributions into the theoretical explanation of Brownian motion, establishing molecular structure of matter and creation of computer simulations/experiment approach. A discussion in Section 4 concludes the paper.

\section{Marian Smoluchowski, Brownian motion and molecular structure of matter}

Marian Smoluchowski (Maryan Ritter von Smolan Smoluchowski, *28 May 1872 - †05 September 1917) was born in Vorder-Brühl (presently a part of Mödling, a suburb of Vienna). In 1890, he finished the Collegium Theresianum, where in particular he made acquaintance with Kazimierz Twardowski (1866-1938). During 1890-94, Marian Smoluchowski studied physics at the University

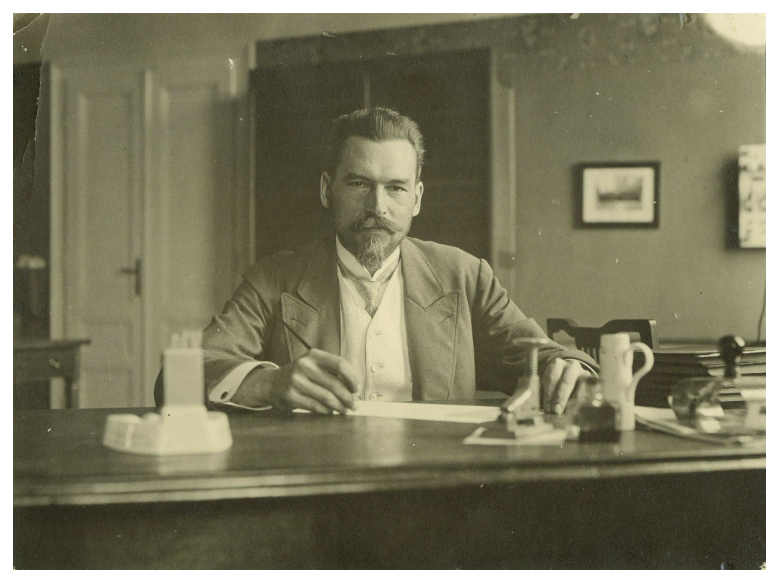

Fig. 1. Marian Smoluchowski at his desk. At present, we cannot confirm whether this photo was taken in Lviv (cf. [17]) or in Kraków. of Vienna. After accomplishing military service in 1894-95, he received his doctoral degree in 1895 for the work Akustische Untersuchungen über die Elasticität weicher Körper /Acoustic studies of the elasticity of soft bodies] [11]. Often, Jožef Stefan is mentioned as Smoluchowski's advisor $[4,12,13]$. However, according to the information obtained from the Archive of the University of Vienna, his doctoral advisors were Franz Exner (1849-1926) and Viktor von Lang (1838-1921), cf. also [14,15].

After visiting several scientific centers abroad (Paris in 1895/96, Glasgow in 1896/97, and Berlin in 1897), Marian Smoluichowski returned to Austria, where he obtained his habilitation in Physics from the University of Vienna. Following the suggestion of Kazimierz Twardowski, then a philosophy professor at the University of Lviv, Marian Smoluchowski

Mathematical Modeling and Computing, Vol. 5, No. 2, pp. 99-107 (2018) 
applied for a position at the University of Lviv and became a Privatdozent of mathematical physics there in 1899. In the fall of the same year, he occupied the Chair of Mathematical (Theoretical) Physics after the late Professor Oskar Fabian. In 1900, Marian Smoluchowski became an extraordinary (associate) professor and was soon promoted to the ordinary (full) professor in 1903. During the academic year 1906/07, he was Dean of the Philosophical Faculty of the University of Lviv.

Marian Smoluchowski spent in total fourteen years at the University of Lviv, where he worked till 1913. He was then invited to occupy the Chair of Experimental Physics at the Jagiellonian University in Kraków after the late Professor August Witkowski. In 1916/17, Marian Smoluchowski served a Dean of the Philosophical Faculty and was elected Rector of the Jagiellonian University in June 1917. Unfortunately, he passed away in just a few months, on September 05, 1917. For more biographical details, see [16-19].

While working at the University of Lviv, Marian Smoluchowski authored over ninety publications [20]. The variety of subjects covered by these works is astonishing: Brownian motion, critical opalescence phenomenon, properties of viscous liquids, heat conduction in rarefied gases and in pulverized medium, etc. Moreover, he contributed to the topic of mountain formation, dissemination of scientific knowledge, as well as authored several works of didactic nature in the field of thermodynamics and electromagnetism. In 1908, Marian Smoluchowski's student, Jan Jakub Stock (1881-1925), defended at the University of Lviv his doctoral thesis entitled Ruch kuli w cieczy lepkiej, równolegle do ściany nieskończenie dużej [Movement of a ball in a viscous liquid, parallel to an infinitely large wall] [21,22]. This is the only Smoluchowski's student we are aware of.
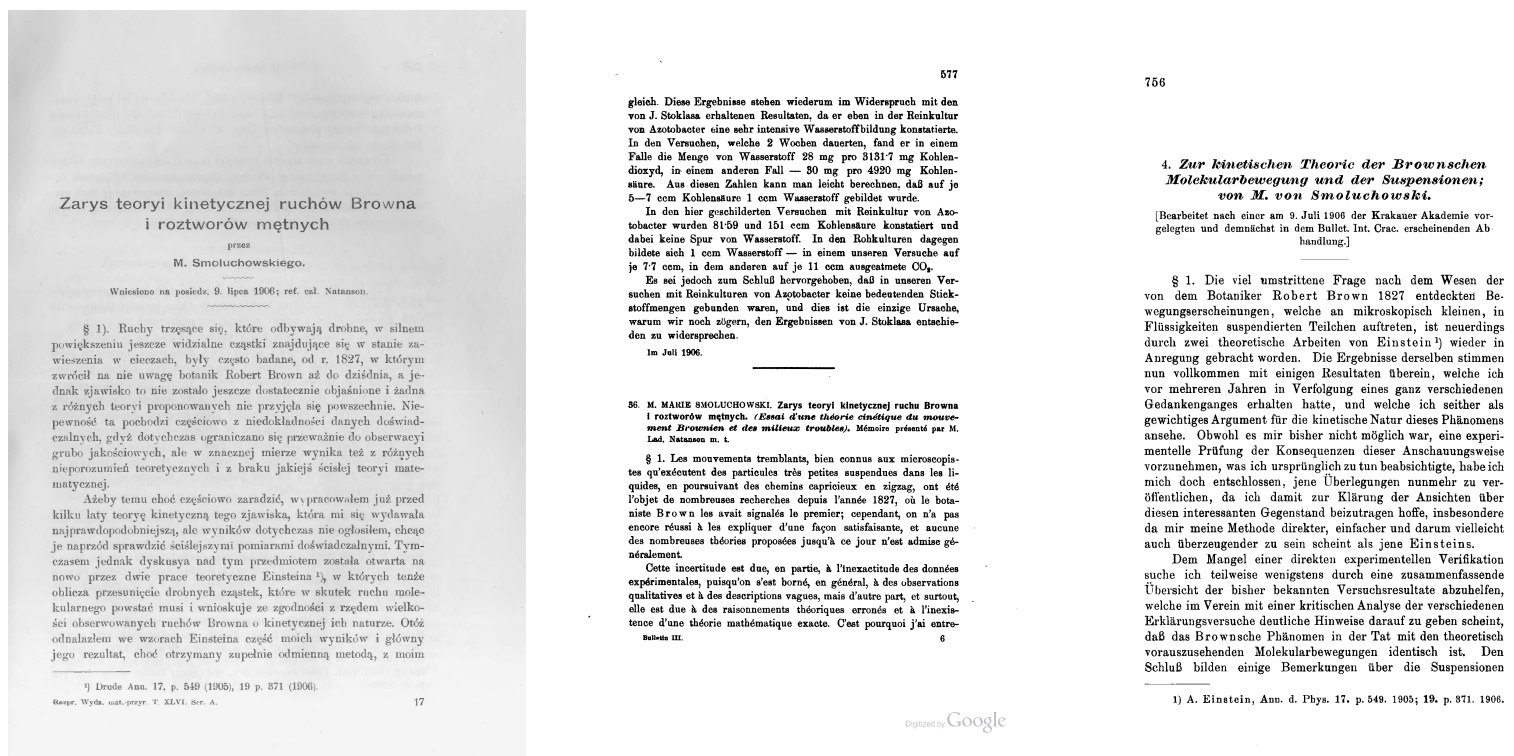

Fig. 2. Brownian motion paper. The image on the left is the first page of the original Polish text published in Rozprawy Wydziatu matematyczno-przyrodniczego Akademii Umiejętności. Serya III. The middle image is the first page of the French translation published in Bulletin international de l'Académie des sciences de Cracovie. Classe des sciences mathématiques et naturelles. The image on the right is the first page of the paper published in Annalen der Physik. The latter contains a note that this is an edited version of the treatise published in the Bulleting of the Kraków Academy.

We, however, return two years earlier to mention one of Marian Smoluchowski's major contributions into the development of the kinetic theory and molecular structure of matter, his famous 1906 paper on Brownian motion [8]. This work was originally presented to the Polish Academy of Learning in Kraków (Polska Akademia Umiejętności) on the 9th of July, 1906, by Władysław (Ladislas) Natanson (1864-1937) and published in the bulletins of the Academy in Polish [23] and French [24], see Fig. 2. One of the key results of this paper was that the mean (or, to be more precise, the root-mean-square) displacement $\Lambda$ of a Brownian particle is proportional to the square root of time $\tau$, in Smoluchowski's 
notation:

$$
\Lambda=C \sqrt{2 \tau}
$$

Being expressed, upon application of Stokes's law, via the particle radius and some other quantities, like temperature and the viscosity of liquid, the results for the mean displacement obtained by Smoluchowski and Einstein differ only by a numerical factor [3,8]. One of most important outcome of these studies was discovery of the existence a relation between the laws of motion of visible and accessible for direct measurement suspended in a molecular solvent Brownian particles and the laws of motion of invisible molecules of that solvent. The latter revealed various experimental possibilities for verifying the quantities characterizing molecular systems, e.g., Avogadro's number through measuring the viscosity, the critical opalescence, the molecular light scattering, etc.

It worth to mentioning that Smoluchowski was not the only Lviv researcher to contribute to the study of the Brownian motion. Back in 1881, Łukasz BoDASzEWSKI (1849-1908), then an assistant at the Higher Polytechnic School in Lviv, observed the Brownian motion in gases using an enhanced microscope of his own construction [25-27]. Marian Smoluchowski referred to Lukasz Bodaszewski' observations in his works [28] and it is quite likely that the two scientists met in Lviv.

In 1917, Smoluchowski published his last papers [29,30] on the theory of kinetics and colloidal suspensions that extended molecular theory of liquid matter on colloidal dispersions. Shortly after that, Marian Smoluchowski passed away at the age of 45. By surveying his pioneering contribution in molecular theory, as well as achievements in formulating the probabilistic approach and clarification the ergodic hypothesis from the perspective of science evolution in post-Smoluchowski era, one could find their relevance to the appearance of Monte Carlo and molecular dynamics computer simulation approaches, that are powerful research tools nowadays. Invention of one of them, namely, Monte Carlo method is closely related with the name of Stanisław Ulam and this is the subject of the following Section.

\section{Stanisław Ulam and Monte Carlo simulations}

In contrast to Marian Smoluchowski, who came to Lviv as already established researcher and spent here most productive years of his research career, Stanisław Marcin Ulam (*13 April 1909 - †13 May 1984) was born in Lviv. At age ten in 1919 Ulam entered Lviv Gymnasium VII, from which he graduated in 1927. After that he studied mathematics at the Lviv Polytechnic, where under the supervision of topologist Kazimierz Kuratowski, in 1932 he received his master degree and in 1933 his doctoral degree for the work O teorji miary w ogólnej teorji mnogoći [On the theory of measure in general set theory] [31]. Curiously, it was a rather untypical situation as the degree was awarded in mathematical sciences while mostly Polytechnic did it in technical sciences. Another known example is Jan Blaton, who received his doctoral degree in 1932 from the Lviv Polytechnic in the field of physical sciences [32,33].

Stanisław Ulam is one of representatives of the Lviv School of Mathematics founded by Hugo Steinhaus and Stefan Banach, who were professors at the University of Lviv. Besides already mentioned Kazimierz Kuratowski, among other members of this school were Stanisław Mazur, Mark Kac, Włodzimierz Stożek. The scientific interests of Ulam from the Lviv period were mostly linked to the set theory, measure theory, and topology. Later, he worked also in numerous other domains, like non-linear systems, branch processes, computational techniques, etc. [31].

In 1935, Stanisław Ulam was invited by John von Neumann to visit the Institute for Advanced Study in Princeton. He used to return to Lviv in summers during 1936-39 and finally moved to the USA in 1939. During 1941-43, Stanisław Ulam worked at the University Wisconsin-Madison. In 1944, he moved to the Los Alamos National Laboratory in New Mexico to join the Manhattan project. After the war, Stanisław Ulam shortly worked as a professor at the University of Southern California in Los Angeles. He returned to Los Alamos in 1946 and remained at his position there till 1965, then worked

Mathematical Modeling and Computing, Vol. 5, No. 2, pp. 99-107 (2018) 
at the University of Colorado at Boulder. During 1974-84, he was a professor at the University of Florida. Stanisław Ulam died in 1984 in Santa Fe [31,34] and is buried in Montparnasse Cemetery in Paris.

During his scientific career Stanisław Ulam contributed to various fields of science that is well documented in his mathematical autobiography [35]. One of the most important his achievement is the Monte Carlo method of solving mathematical problems by employing statistical sampling through the use of random numbers that over the decades has been applied successfully to a vast number of scientific problems. The essence of the method could be well understood from unpublished remarks made by Ulam in 1983 that in 1987 were cited by Eckhardt [36]: "The first thoughts and attempts I made to practice [the Monte Carlo method] were suggested by a question which occurred to me in 1946 as I was convalescing from an illness and playing solitaires. The question was what are the chances that a Canfield solitaire laid out with 52 cards will come out successfully? After spending a lot of time trying to estimate them by pure combinatorial calculations, I wondered whether a more practical method than 'abstract thinking' might not be to lay it out say one hundred times and simply observe and count the number of successful plays. This was already possible to envisage with the beginning of the new era of fast computers, and I immediately thought of problems of neutron diffusion and other questions of mathematical physics, and more generally how to change processes described by certain differential equations into an equivalent form interpretable as a succession of random operations. Later... Iin 1946, I] described the idea to John von Neumann and we began to plan actual calculations."

By mentioning the application of Monte Carlo method to the neutron diffusion problem, Ulam meant that it will be able to provide an estimate of the neutron multiplication rate for a collection of neutrons within a given geometry at a fixed time $t$, i.e., what fraction of neutrons will survive after a short time interval $\Delta t$ [38].

In March 11, 1947 von Neumann wrote letter to Robert Richtmyer, theoretical division leader at Los Alamos, about the "possibility of using statistical methods to solve neutron diffusion and multiplication problems, in accordance with the principle suggested by Stan Ulam." Von Neumann prepared a "computing sheet" that specified the sequence of required calculations. He felt that such computations were within the logical capacity of the ENIAC and estimated that the computational time required to trace 100 primary neutrons through 100 collisions would take about five hours [38].

This was the first modeling application of Monte Carlo simulations. As is described by "history-of-science buffs" Gass and Assad from the University of Maryland [38], that von Neumann's letter, together with his computing notes and Richtmyer's letter of response,

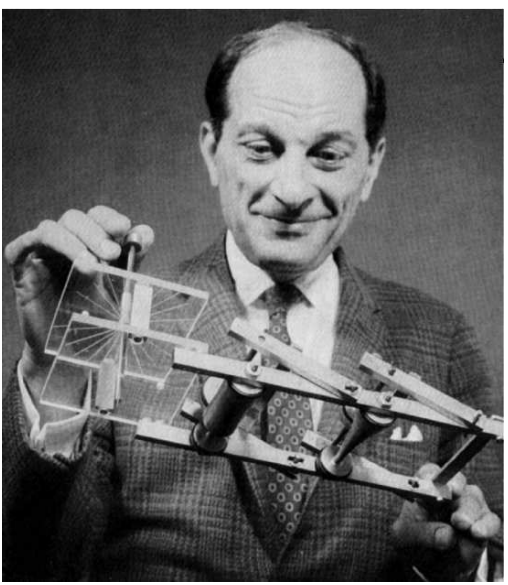

Fig. 3. Stanisław Ulam holding an analog computer devised by Enrico Fermi and known as the Monte Carlo trolley, later dubbed the FERMIAC [37]. formed the first written report on the Monte Carlo method. It was issued as a classified Los Alamos report entitled "Statistical methods in neutron diffusion" (April 9, 1947). The report listed R. D. Richtmyer and J. von Neumann as the writers and specified that it represented "work done" by Ulam and von Neumann. The report contained 22 pages, was issued in only eight copies, and remained classified until 1959. It referred to the Monte Carlo method as "the Statistical Method."

Application of Monte Carlo method to explore the properties of molecular system, i.e., molecular simulations, concerns an application of the Ulam's formulated Monte Carlo ideology to evaluate the many-dimensional integrals that determine partition function of the molecular system. It has been already mentioned in Introduction that pioneering paper on molecular simulations was published in 1953 by Metropolis et al. [10]. That study has been performed on one of the first computing machine MANIAC and was dealing with two-dimensional system composed of 224 hard-core molecules. Since then many modifications of the computing algorithms were performed $[39,40]$ as well as few generations of computing machines were changed. To illustrate the progress, in 2013 Engel et al. [41] have reported 
Monte Carlo simulations of the same two-dimensional system but with system size of $1024^{2}$ hard-core molecules, that $5 \times 10^{5}$ times larger than it was 65 years ago.

\section{Afterwords}

During more than one century after Marian Smoluchowski left to Jagiellonian University in 1913, the Department for Theoretical Physics of Lviv University was chaired by many physicists who were working in various fields of theoretical physics. In 1969 one of them, Ihor Yukhnovskii (chair during 1958-71), whose major interest was statistical physics, founded in Lviv the Institute for Condensed Matter Physics (ICMP). Institute belongs to the National Academy of Sciences of Ukraine and its main task is to carry out fundamental research in theoretical physics and condensed matter physics. Among various directions of the research activities there are computer simulations of physical and chemical processes in molecular solids and fluids. Few years after launching in 2001 the first Ukrainian computational cluster there was decided to create the Department for computer simulations of manyparticle systems. Nowadays ICMP is leading institution in molecular simulations in Ukraine while collaborative research projects are spread around the world. Besides the Ulam's Monte Carlo method, other simulation techniques such as classical and ab initio molecular dynamics, dissipative particle dynamics are widely used here.

The studies performed include the development of computational algorithms $[42,43]$ as well as investigations of the structure, thermodynamics and dynamical properties of the various condensed matter systems. The particular systems under study include simple fluids [44,45], water and ice [46], liquid crystalline systems [47], proteins [48], etc.

To pay tribute to the legacy of Marian Smoluchowski for his pioneering contributions to the development of the fields of molecular theory, Lviv hosted two Workshops in 2009 [49] and 2011 [50] and the International conference on statistical physics in 2012 [51]. On the occasion of the 70th anniversary of the invention of Monte Carlo method in 2017, the Ulam Computer Simulation Workshop on challenges and opportunities in molecular simulations [52] took place. All these meetings brought to Lviv leading researchers on statistical physics and computer simulations who presented an in-depth review of the most recent developments in the field that poses many challenges nowadays.

[1] Ingen-Housz J. Bemerkungen über den Gebrauch des Vergrösserungsglases. In: Vermischte Schriften physisch-medicinischen Inhalts. Uibersetzt und herausgegeben von Nicolaus Carl Molitor. Zweyter Band. Wien: Christian Friderich Wappler (1784), S. 121-126 (in German).

[2] Brown R. A brief account of microscopical observations made on the particles contained in the pollen of plants. London and Edinburgh Phil. Mag. J. Sci. 4 (21), 161-173 (1828).

[3] Mazo R. M. Brownian Motion. Fluctuations, Dynamics, and Applications. Oxford, Clarendon Press (2002).

[4] Pohl W. G. The theory of Brownian motion - one hundred years old. In: The Global and the Local: The History of Science and the Cultural Integration of Europe, Proceedings of the 2nd International Conference of the European Society for the History of Science (Cracow, 2006), edited by M. Kokowski. The Press of the Polish Academy of Arts and Sciences, Cracow (2007), p. 419-424.

[5] https://www.physik.uni-augsburg.de/theo1/hanggi/History/BM-History.html.

[6] Perrin J. La loi de Stokes et le mouvement brownien. C. R. Acad. Sci. Paris. 147, 475-476 (1908); idem, L'origine de mouvement brownien. C. R. Acad. Sci. Paris. 147, 530-533 (1908), (in French).

[7] Einstein A. Über die von der molekularkinetischen Theorie der Wärme geforderte Bewegung von in ruhenden Flüssigkeiten suspendierten Teilchen. Ann. Phys. 322 (8), 549-560 (1905), (in German).

[8] von Smoluchowski M. Zur kinetischen Theorie der Brownschen Molekularbewegung und der Suspensionen. Ann. Phys. 326 (14), 756-780 (1906).

[9] Badino M. Probability and Statistic in Boltzmann's Early Papers on Kinetic Theory. Dublin Core, Chicago (2006).

Mathematical Modeling and Computing, Vol. 5, No. 2, pp. 99-107 (2018) 
[10] Metropolis N., Rosenbluth A. V., Rosenbluth M. N., Teller A. H., Teller E. Equation of State Calculations by Fast Computing Machines. J. Chem. Phys. 21 (6), 1087-1092 (1953).

[11] von Smoluchowski M. Akustische Untersuchungen über die Elasticität weicher Körper. Sitzungsber. kaiserl. Akad. Wiss. Wien. Math.-naturwiss. Kl. 103 (II.a), 739-72 (1894), (in German).

[12] MontrollE. W. On the Vienna School of statistical thought. AIP Conference Proceedings. 109 (1), 1-10 (1984).

[13] Rovenchak A. Lviv period for Smoluchowski: Science, teaching, and beyond. Condens. Matter Phys. 15 (4), $40002(2012)$.

[14] Mehra J., Rechenberg H. The Historical Development of Quantum Theory. Vol. 5. Springer (2001).

[15] Coen D. R. Vienna in the Age of Uncertainty: Science, Liberalism, and Private Life. University of Chicago Press (2007).

[16] Teske A. Marian Smoluchowski: życie i twórczość. PWN, Kraków, 1955 (in Polish); German translation: Teske A., Marian Smoluchowski: Leben und Werk, Wrocław-Warszawa-Kraków-Gdańsk, 1977.

[17] Góra P. E. Fluktuacje wokół nas. Dziedzictwo Mariana Smoluchowskiego. PAUza Akademicka. Tygodnik Polskiej Akademii Umiejętności. 9 (380-381), 4-5 (2017).

[18] Ulam S. Marian Smoluchowski and the theory of probabilities in physics. Am. J. Phys. 25 (7), 475-481 (1957).

[19] SzymanskiW.W., Posch H.A. Marian Wilhelm Theofil von Smoluchowski. http://www.iara.org/ AerosolPioneers.htm

[20] http://ktf.lnu.edu.ua/cgi-bin/KTF/select.cgi?Smoluchowski

[21] Hoborski A. Prof. dr Jan Stock wspomnienie pośmiertne. Przegląd Górniczo-Hutniczy. 27, 454-457 (1925), (in Polish).

[22] Rovenchak A. Department for Experimental Physics, University of Lviv, in 1872-1939: Contributions to biobibliography. J. Phys. Stud. 22 (4), 4002 (2018).

[23] Smoluchowski M. Zarys teoryi kinetycznej ruchów Browna i roztworów mętnych. Rozpr. Wydz. matem.przyrodn. Ak. Umiejęt. Ser. III 6A, 257-281 (1906), (in Polish).

[24] Smoluchowski M. Essai d'une théorie cinétique du muovement Brownien et des milieux troubles. Bull. Int. Acad. Sci. Cracovie. Cl. sci. math. nat. 577-602 (1906), (in French).

[25] Bodaszewsky L. J. Rauch und Dampf unter dem Mikroskop. Dinglers Polytechn. J. 239, 324-325 (1881), (in German).

[26] Kozhushko B.V., Shenderovskyj V.A. Zabute v nauci im'ja (Lukash Bodashevskyj - fizyk i hidromekhanik). Visnyk Nacionalnoho Tekhnichnoho Universytetu "KhPI". 64, 71-76 (2011), (in Ukrainian).

[27] Wróblewski A. K. Polish physicists and the progress in physics (1870-1920). Techn. Trans. Fund. Sci. 111 (1), 255-273 (2014).

[28] Mehra J. Golden Age Of Theoretical Physics. Vol. 1. World Scientific (2001).

[29] Smoluchowski M. Versuch einer mathematischen Theorie der Koagulationskinetic kolloider Lösungen. Z. Phys. Chem. 92U (1), 129-168 (1917), (in German).

[30] Smoluchowski M. Grundriß der Koagulationskinetik kolloider Lösungen. Kolloid-Zeitschrift. 21, 98-104 (1917), (in German).

[31] Mycielski J. Stanisław Marcin Ulam (1909-1984). Rocz. Pol. Tow. Matem. Ser. II: Wiad. Matem. 29, 21-37 (1990), (in Polish).

[32] Program Politechniki Lwowskiej na rok akademicki 1933/34. Lwów, 1933 (in Polish).

[33] Ponedilok G. V., Rovenchak A. A. To the history of theoretical physics studies at the Lviv Polytechnic. J. Phys. Stud. 21, 1003 (2017).

[34] Bazylevych L., Guran I., Zarichnyi M. Lwów period of S. Ulam's mathematical creativity. Techn. Trans. Fund. Sci. 2-NP, 33-39 (2015).

[35] Ulam S. Adventures of a Mathematician. University of California Press (1976).

[36] Eckhardt R. Stan Ulam, John von Neumann, and the Monte Carlo Method. In: From Cardinals to Chaos: Reflections on the life and legacy of Stanislaw Ulam. Cambridge, Cambridge University Press (1989). First 
published in Los Alamos Science Special Issue, 131-141 (1987); https://permalink.lanl.gov/object/ tr?what=info: lanl-repo/lareport/LA-UR-88-9068.

[37] Giesler G. C. MCNP software quality: Then and now. Los Alamos National Laboratory Report LA-UR-00-2532 (2000); https://permalink.lanl.gov/object/tr?what=info:lanl-repo/lareport/ LA-UR-00-2532.

[38] Gass S. I., Assad A. A. Model World: Tales from the Time Line-The Definition of OR and the Origins of Monte Carlo Simulation. Interfaces. 35 (5), 429-435 (2005).

[39] Allen M. P., Tildesley D. J. Computer Simulation of Liquids. New York, Oxford University Press (2002).

[40] Frenkel D., Smit B. Understanding Molecular Simulation: From Algorithms to Applications. 2nd ed. London, Academic Press (2002).

[41] Engel M., Anderson J. A., Glotzer S. C., Isobe M., Bernard E. P., Krauth W. Hard-disk equation of state: First-order liquid-hexatic transition in two dimensions with three simulation methods. Phys. Rev. E. 87, 042134 (2013).

[42] Omelyan I. P., Mryglod I. M., Folk R. Construction of high-order force-gradient algorithms for integration of motion in classical and quantum systems. Phys. Rev. E. 66, 026701 (2002).

[43] Omelyan I. P., Mryglod I. M., Folk R. Symplectic analytically integrable decomposition algorithms: classification, derivation, and application to molecular dynamics, quantum and celestial mechanics simulations. Computer Phys. Commun. 151 (3), 272-314 (2003).

[44] Trokhymchuk A., Alejandre J. Computer simulations of liquid/vapor interface in Lennard--Jones fluids: Some questions and answers. J. Chem. Phys. 111 (18), 8510-8523 (1999).

[45] Simeoni G. G., Bryk T., Gorelli F. A., Krisch M., Ruocco G., Santoro M., Scopigno T. The Widom line as the crossover between liquid-like and gas-like behaviour in supercritical fluids. Nature Phys. 6, 503-507 (2010).

[46] Bryk T., Haymet A. D. J. Ice 1h/water interface of the SPC/E model: Molecular dynamics simulations of the equilibrium basal and prism interfaces. J. Chem. Phys. 117 (22), 10258-10268 (2002).

[47] Wilson M. R., Ilnytskyi J. M., Stimson L. M. Computer simulations of a liquid crystalline dendrimer in liquid crystalline solvents. J. Chem. Phys. 119 (6), 3509-3515 (2003).

[48] Baumketner A., Bernstein S. L., Wyttenbach T., Bitan G., Teplow D. B., Bowers M. T., Shea J. E. Amyloid $\beta$-protein monomer structure: A computational and experimental study. Protein Sci. 15 (3), 420-428 (2006).

[49] Smalyukh I., Trokhymchuk A. Planer-Smoluchowski Soft Matter Workshop on Liquid Crystals and Colloidal Dispersions. Condens. Matter Phys. 13 (3), 37101 (2010).

[50] http://www.icmp.lviv.ua/pssm2011.

[51] http://www.icmp.lviv.ua/statphys2012.

[52] http://icmp.lviv.ua/ucsw2017. 


\title{
Від броунівського руху до молекулярного комп'ютерного експерименту
}

\author{
Ровенчак A. ${ }^{1}$, Трохимчук A. $^{2}$ \\ ${ }^{1}$ Кафедра теоретичної фізики, Лъвівсъкий начіональний університет імені Івана Франка, \\ вул. Драгоманова, 12, Львів, 79005, Україна \\ ${ }^{2}$ Інститут фізики конденсованих систем НАН Украӥни, \\ вул. Свенцічъкого, 1, Львів, 79011, Україна
}

Наведено короткий історичний огляд про внесок двох всесвітньо відомих львівських наукових дослідників - Маріана Смолуховського та Станіслава Улама - у розвиток сучасних галузей фізичної науки, таких як молекулярне моделювання, комп'ютерний експеримент та молекулярна інженерія, висвітлено їх зв'язок із останніми дослідженнями, проведеними у львівських університетах та науково-дослідних установах.

Ключові слова: історія науки, метод Монте-Карло, метод молекулярної динаміки, першопринципні ар іпіtіо симуляиї

2000 MSC: 01A60, 82-03, 82C40, 82D30, 60J65

УДК: 53(091), 501, 533.723, 544.77

Mathematical Modeling and Computing, Vol. 5, No. 2, pp. 99-107 (2018) 